\title{
THE IMPLEMENTATION OF INTERNAL COMMUNICATION SYSTEM AS A WAY TO COMPANY EFFICIENCY
}

\author{
Jana Holá, Marcel Pikhart
}

\section{Introduction}

Internal communication as a managerial discipline has become important as a managerial discipline only recently. By its gradual development, it is now perceived as a tool, which - when working efficiently - can become a strong motivator, however, on the other hand a strong distress factor as well. Functioning internal communication becomes an important work condition and its content is connected to marketing, human resources and managerial work with its most important aims, i.e. to focus on ensuring information support, setting processes for work performance, making conditions for cooperation and climate for desired work performance and staff attitudes.

Internal communication had to fight for its place by its gradual development connected to perception of the employee as one of the greatest asset for the company and as a company competitive advantage. Companies realize that communication helps employees understand what is demanded from them. Communication has recently moved its focus on sharing company goals and on the fact that its efficiency is manageable by system settings from the top of the company (top-down approach). The managers in successful companies realize their responsibility for both the company and their own communication in the company. Internal communication, thus, becomes a natural part of the whole business communication. Currently this communication is challenged by new technologies and globalization, which can mislead out attention from its basic importance, i.e. internal communication as a part of strategy management, and it ought to be managed by the system that can create the frame for effective communication [6]. And moreover, how efficiently the companies communicate to their stakeholders will determine how successful a firm is internationally. Internal communication is an integral part of all company communication and therefore it should be implemented in the whole company strategy [8], [11].

\section{Theoretical Background: Internal Communication as a Strategic and Systematic Issue}

Internal communication has a crucial importance on the staff engagement, which increases profitability of a company and supports its competitiveness as the research by Gallup [5], Yates [17], Tan [15] and Pikhart [12], [13] confirm. Efficient communication in a company has become a necessary work condition which creates the environment of cooperation and connects the expectations of employees with the ones of the company. On the other hand, inefficient communication can become a strong distress factor and can paralyse the basic functions of the company, which is also supported by the data from the European Survey of Enterprises on New and Emerging Risks by European Agency for Safety and Health at Work [4].

Communication is the process of the exchange of ideas, thoughts, opinions and views. When it comes to company communication, this basic understanding of the communication process is not sufficient. Company communication, including external and internal communication, is a specific field of the organizational management that requires knowledge and comprehension. Communication is integral to the stability and success of a business for a simple reason: businesses are 
made up of people [16]. If company employees are not satisfied as individuals, they will not be productive and will not yield favourable results [14]. Various research and studies have proved that effective communication strongly affects all processes in the organization because internal communication creates a crucial bridge between various processes and activities that move the organization forward.

These are the four crucial areas to consider when setting the right internal communication strategy:

- Setting up formal and basic level of communication for ensuring basic information needs necessary for work performance, mostly, company literature but also information and communication infrastructure.

- Setting up communication for cooperation through personnel and managerial communication.

- Setting up knowledge management for retaining and development of know-how, e.g. in the system of internal training and workshops.

- Setting up internal PR and forming desired work performance in employees and developing the stability and low fluctuation of employees [7].

The management of internal communication represents and includes, as mentioned above, the activities of human resources management, marketing communication and management as such. Therefore it is not a simple and straightforward activity but goes through all the company processes.

It has been observed that the internal communication process is generally not considered and solved systematically in small companies up to 25 employees. Active management of internal communication processes is connected with the increase in number of employees. In these small companies the meaning of internal communication is dispraised by the management and quite often the managers do not comprehend the system complexity of internal communication processes. In practice, the companies have to handle external communication on a daily basis, prefer the external partners but do not appreciate its internal partners - i.e. the employees. The managers often focus merely on technical solving of communication, on technical information and communication infrastructure [6].
Watson Wyatt's research has found convincing evidence that the companies with highly effective internal communication practices produce superior financial results and enjoy greater organizational stability. This study provided proof for the strong correlation between communication effectiveness, organizational turnover and financial performance [17]. The implementation of internal communication into strategic management is considered to be a necessary condition for efficient internal communication in a company [10]. The implementation of internal communication into strategic management of the company means mainly the accountability of the management for internal communication as a tool which leads to higher morale, employee engagement and accepting their importance as communicators and partners and realizing the fact that they are considered to be the most important asset for the company as highlighted by Armstrong [1] and Louhiana-Salmien [9].

\section{Survey Methodology}

In the conducted research the authors have tried to test the hypothesis that the strategic and systematic internal communication is more efficient for the company from the viewpoint of its profitability and competitiveness. Only the companies with more than 50 employees were included in the research sample because it is clear from the previous research [6] that the small companies solve the internal communication more or less intuitively and ad hoc as mentioned above.

A survey was carried out by LMC, s.r.o. (LMC Ltd. is one of the leading European erecruitment companies) in cooperation with the Institut interní komunikace (Institute of Internal Communication) during the spring 2012 and it brought several interesting findings regarding internal communication in Czech companies. The authors of this article are members of the Institute of Internal Communication and can handle the data of the survey. The Institute of Internal Communication is an independent nonprofit organization made up of members who are professionally involved or have an interest in internal communication.

The request to fill in the questionnaire was sent by an e-mail to 18,000 companies in the Czech Republic cooperating with LMC Ltd. In the observed category according to the number 
of employees the managers of 252 collaborating companies completed an online questionnaire. The companies are divided according to the number of employees, region, field of operations, whether they are an employer, employment agency or non-governmental organization, and also according to the company ownership, i.e. Czech, foreign or a combination of both. These demographic parameters come from the LMC Ltd. company methodology.

The detailed overview of the researched companies is shown in Table 1. The column "IC system" shows the percentage of the companies where internal communication (IC) is managed out of the total number of the companies. Internal communication system can be defined as managing internal communication with the set of rules, channels, plans, defined competencies and responsibilities. On the other hand, internal communication in strategy was defined within the context of standardized internal communication closely connected to the company strategy. The column "IC in strategy" shows the percentage of the companies which implement internal communication in the company strategy out of the total number of the companies in the given category.

\section{Tab. 1: Overview of the companies according the number of employees}

\begin{tabular}{l|c|c|c} 
Number of employees & Frequency & $\begin{array}{c}\text { IC system } \\
\text { (percentage of the } \\
\text { total number) }\end{array}$ & $\begin{array}{c}\text { IC in strategy } \\
\text { (percentage of the } \\
\text { total number) }\end{array}$ \\
\hline 50 to 250 & 130 & $65 \%$ & $45 \%$ \\
\hline 251 to 499 & 51 & $69 \%$ & $43 \%$ \\
\hline 500 to 1000 & 27 & $74 \%$ & $41 \%$ \\
\hline 1,000 to 10,000 & 42 & $83 \%$ & $55 \%$ \\
\hline More than 10,000 & 2 & $100 \%$ & $100 \%$ \\
\hline Total & 252 & $70 \%$ & $23 \%$ \\
\hline
\end{tabular}

Source: Own

\section{Survey Results}

One of the most important intentions of the research was to find out if strategic and systematic management of internal communication can influence the company internal communication efficiency. For the case of the research the systematic management of internal communication is defined as managing internal communication by a set of rules, plans, channels, alongside with defined competencies and responsibility; and strategic management was defined in the context of delimited concept of internal communication connected to the company strategy.

The respondents answered the questions if internal communication is managed systematically (yes/no) and if it is a part of strategic management of the company (yes/no). The efficiency of internal communication was evaluated by the respondents (managers) subjectively according to their personal opinions on a scale from 1 (minimal) to 7 (maximal), and efficient communication was defined as the concept where all the participants know everything they need to do, who to cooperate with, why to do that on time, and the situation where there are no or limited misunderstandings. Communication ensures the availability of information for the work performance and cooperation, internal PR sufficiently ensures and supports team spirit in the staff, declared social policy ensures mutual respect and justice, stabilizes employees, and the efficient information and communication infrastructure ensures communication support.

The data of communication efficiency evaluation were divided into the groups according to the fact if the internal communication is a part of the company strategy or if the internal communication is managed systematically. Box Plots in the Fig. 1 individually represent the efficiency evaluation of internal communication in the groups of the companies according to the fact if they implement it into systematic internal 
communication management or include it in strategic management. The graphs in the Fig. 1 represent the spread of the levels of evaluation.

In individual groups there is a marked difference. In the group of the companies which systematically manage internal communication is the value of median of the overall internal communication efficiency much higher than the similar value in the group of companies which do not manage internal communication systematically. The lowest levels of internal communication efficiency evaluation (median) are reached by the companies which lack the systematic internal communication management.
In the group of the companies divided according to internal communication in strategy is the level of median of the evaluation of internal communication efficiency also higher than in the second group of the companies which do not include internal communication in their strategy. The other graphs show the combinations of the companies which include internal communication into strategic and systematic management. The lowest levels of median in the evaluation represent the companies which manage their internal communication neither systematically nor include it into their strategy.

\section{Fig. 1: Box Plots of evaluation of internal communication efficiency in the groups of the companies according to strategic management}

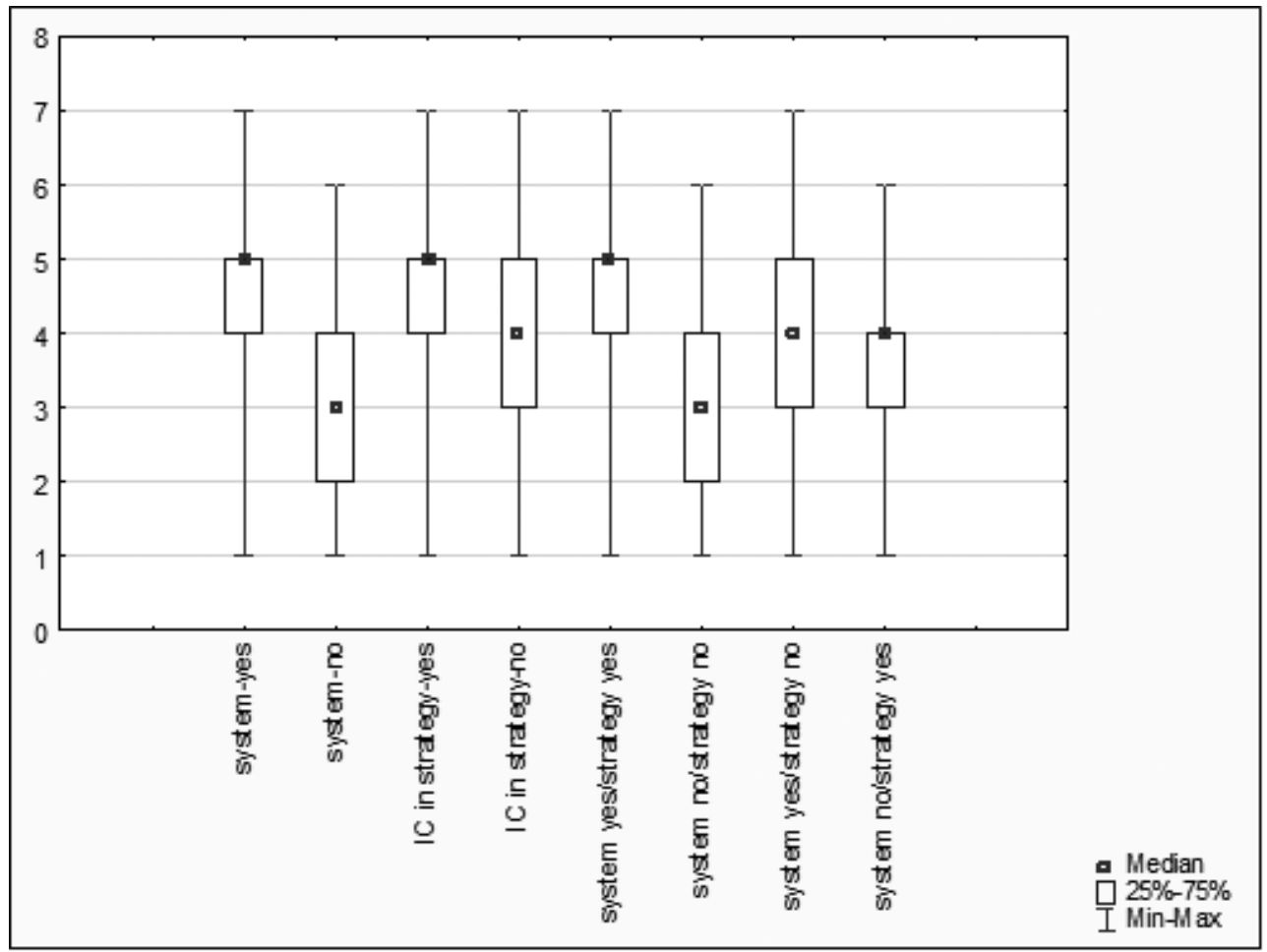

Source: Own

Because of the marked difference in the evaluation of the efficiency in the individual groups, the data were tested on statistically important difference by nonparametric tests (the data do not spread normally). Mann-Whitney Test was used for comparing the two independent samples. The final results are shown in the Tab. 2 . Simultaneously, the hypothesis test was carried out regarding the strategic and systematic management of internal communication and the Pearson's-chi2 test was used. All the described tests were carried out in the STATISTICA@ software. 


\begin{tabular}{|c|c|}
\hline Working hypothesis & Tested hypothesis on the significance level $\alpha=0,05$ \\
\hline \multirow{2}{*}{$\begin{array}{l}\text { The companies where internal communication is a } \\
\text { part of strategic management reach better evaluation } \\
\text { of the efficiency of internal communication than the } \\
\text { companies which do not include internal } \\
\text { communication in strategic management. }\end{array}$} & $\mathrm{H}_{0}$ : the difference in the evaluation values in both groups is zero; \\
\hline & $\mathrm{H}_{0}$ rejected, $\mathrm{p}=7.056 \mathrm{E}-07<\mathrm{a}$ \\
\hline \multirow{2}{*}{$\begin{array}{l}\text { The companies where internal communication is } \\
\text { managed systematically reach better evaluation of } \\
\text { efficiency of internal communication than the } \\
\text { companies where internal communication is not } \\
\text { systematically managed. }\end{array}$} & $H_{0}$ : the difference in the evaluation values in both groups is zero; \\
\hline & $H_{0}$ rejected, $p=2.006 E-10<a$ \\
\hline \multirow{2}{*}{$\begin{array}{l}\text { The companies where internal communication is a } \\
\text { part of both strategic management and also managed } \\
\text { systematically. }\end{array}$} & $\mathrm{H}_{0}$ : no difference between experimental and expected frequency (the difference is zero); \\
\hline & $H_{0}$ rejected, $p=0.00001<a$ \\
\hline
\end{tabular}

By testing the hypotheses were confirmed, i.e. in the companies which systematically manage their internal communication the efficiency evaluation of internal communication is significantly higher than in the ones which do not manage their internal communication systematically. In the companies which include internal communication in their strategic management the evaluation of the efficiency of internal communication is significantly higher than in other companies. The companies which include internal communication in their strategic management also manage this communication systematically and create the most frequent group of companies (almost 40\%) as shown in the Fig. 2.

\section{Fig. 2: The number of companies in groups}

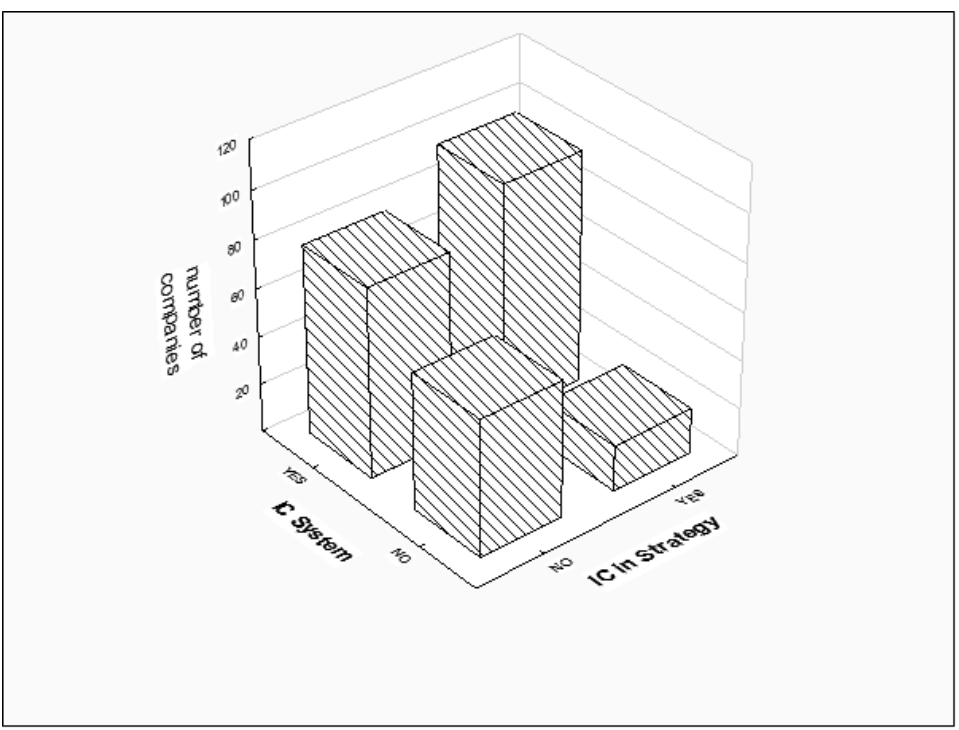


In the statistical data processing no significant differences were observed regarding the number of employees or the form of the company ownership, it is therefore possible to claim that these characteristics do not influence the fact if the companies include internal communication into their strategy and manage it systematically.
Individual pairs of variables were tested by a Pearson's-chi2 test on contingency [3]. In all cases $\mathrm{H}_{0}$ was not rejected therefore there is no relationship between the variables $(p>0.05$, higher level than $\alpha=0.05$ ). The results of statistical test are presented in Table 3. The variable region was used for testing according to the regions in the Czech Republic.

\section{Tab. 3: The results of the contingence hypothesis test}

\begin{tabular}{|l|l|c|}
\hline \multirow{4}{*}{$\mathbf{1}^{\text {st }}$ variable } & $2^{\text {nd }}$ variable & $\begin{array}{r}\text { Tested hypothesis on the significance level } \mathbf{\alpha}=\mathbf{0 . 0 5} \mathrm{H}_{0} \text { : there is no } \\
\text { relationship between variables }\end{array}$ \\
\hline \multirow{5}{*}{ IC system } & Number of employees & $\mathrm{p}=0.13099 ; \mathrm{H}_{0}$ not rejected \\
\cline { 2 - 4 } & Company ownership & $\mathrm{p}=0.57592 ; \mathrm{H}_{0}$ not rejected \\
\cline { 2 - 4 } & Field of operation & $\mathrm{p}=0.23920 ; \mathrm{H}_{0}$ not rejected \\
\cline { 2 - 4 } & Region & $\mathrm{p}=0.19650 ; \mathrm{H}_{0}$ not rejected \\
\hline \multirow{3}{*}{ IC in strategy } & Company ownership & $\mathrm{p}=0.97333 ; \mathrm{H}_{0}$ not rejected \\
\cline { 2 - 4 } & Fumber of employees & $\mathrm{p}=0.31801 ; \mathrm{H}_{0}$ not rejected \\
\cline { 2 - 4 } & Field of operation & $\mathrm{p}=0.96105 ; \mathrm{H}_{0}$ not rejected \\
\cline { 2 - 4 } & Region & $\mathrm{p}=0.58762 ; \mathrm{H}_{0}$ not rejected \\
\hline
\end{tabular}

\section{Conclusion}

In conclusion, from the research carried out it is possible to sum up that the companies which include the management of their internal communication into their strategic management and manage it systematically reach higher levels of internal communication efficiency. Even if the level of internal communication is evaluated subjectively by the management, the research has its importance because the managers themselves evaluate their own company performance.

Systematic setting of internal communication is the basic prerequisite for its optimized performance because it creates the framework in which the communication sets the minimum level of its optimal functions and supports its performance as a tool for the management. Internal communication thus reacts to current challenges of the global world. The increased demand for better communication in a company caused by the external changes in the global and intercultural work environment supported by electronic communication is the basis for implementation of enhanced communication strategies which have the potential to create or set the conditions which support innovativeness, profitability and competitiveness [11].

In any innovative organization, people are considered the greatest asset for the company, as their interaction when communicating is the key to empowerment and teamwork. Innovation is therefore linked to cooperation when we 
combine different perspectives and when we cooperate in high-performance teams across various cultural environments as described by Brunet-Thornton and Bureš [2]. Extensive communication within an organization and between organizations can create competitiveness through partnership with people. Innovation is closely linked to creating and sharing knowledge through various multidirectional communication channels - therefore, the importance of communication and information transfer is crucial. Correct transfer of information, i.e. the right encoding and decoding, is the basic prerequisite for success both in communication and with respect to the profitability of the company as well [12]. The mechanisms for enhancing communication are job rotation, cross-functional teams and projects, communication policy-deployment and review sessions, team briefings and multiple media usage [18]. Internet communication, however, heads this list as the most important means of communication and information transfer today. Correct information transfer, i.e. the right encoding and decoding of information, is the basic prerequisite for success both in communication and with respect to the profitability of the company as well.

To sum up, the only viable, modern, innovative and successful approach to company management and intercultural business communication is to focus on modern communication strategies in the global intercultural environment, creating and maintaining communication on the basis of mutual understanding so that trust is created within an organization and between organisations when doing business internationally and globally. The development of trust and employee involvement is crucial as it strengthens a company's global presence by going beyond a simplistic understanding of communication as the mere transfer of isolated information.

\section{References}

[1] ARMSTRONG, M. Armstrong's Essential Human Resources Management Practice. London: Kogan Page, 2010. ISBN 978-7494-599-01. [2] BRUNET-THORNTON, R., BUREŠ, V. Crosscultural Management: Establishing a Czech Benchmark. E+M Ekonomie a Management. 2012, Vol. 15, Iss. 3, pp. 46-61. ISSN 1212-3609.
[3] EASTERBY-SMITH, M., THORPE, R., JACKSON, P.R. Management Research. 3rd ed. London: Sage Publication, 2008. 368 p. ISBN 9781847871770.

[4] EUROPEAN AGENCY FOR SAFETY AND HEALTH AT WORK. European Survey of Enterprises on New and Emerging Risks. Managing safety and health at work [online]. Bilbao: ESENER European Survey of Enterprises on New and Emerging Risks, 2010 [cit. 2013-06-07]. 160 p. (PDF). Available from: https://osha.europa.eu/ en/publications/reports/esener1_osh_manage ment. ISBN 978-92-9191-327-5.

[5] GALLUP CONSULTING. Employee Engagement: What's Your Engagement Ratio? [online]. Washington, D.C.: Gallup Consulting, 2008 [cit. 2013-08-09]. 12 p. (PDF). Available from: http:// www.gallup.com/strategicconsulting/121535/Empl oyee-Engagement-Overview-Brochure.aspx.

[6] HOLÁ, J. Internal communication in the small and medium sized enterprises. E+M Ekonomie a Management. 2012, Vol. 15, Iss. 3, pp. 32-45. ISSN 1212-3609.

[7] HOLÁ, J. Jak zlepšit interní komunikaci. Brno: Computer Press, 2011. ISBN 978-80-251-2636-3.

[8] JACKSON, P. Corporate Communication for Managers. London: Financial Times/Prentice Hall Books, 1987. 166 p. ISBN 978-0273026884.

[9] LOUHIANA-SALMIEN, L. Business Communication. In BARGIELA-CHIAPPINI, F. (Ed.). The Handbook of Business Discourse. Edinburgh: Edinburgh University Press, 2009. pp. 305-316. ISBN 978-0-7486-2801-8.

[10] MILLER, K. Communication Theories: Perspectives, Processes and Context. 2nd ed. New York: McGraw-Hill, 2004. 352 p. ISBN 9780072937947.

[11] MOHELSKÁ, H., PITRA, Z. Manažerské metody. Praha: Professional Publishing, 2012. ISBN 978-80-7431-092-8.

[12] PIKHART, M. Interkulturní komunikace v globálním obchodě. Perspektiva interkulturního managementu. Hradec Králové: Gaudeamus, 2013. ISBN 978-80-7435-255-3.

[13] PIKHART, M. Current Intercultural Management Strategies: The Role of Communication in Company Efficiency Development. In Proceedings of the 8th European Conference on Management Leadership and Governance. Paphos: Neapolis University, 2012. ISBN 978-1-908272-76-8.

[14] SMITH, L. Effective Internal Communication. London: Kogan Page, 2008. ISBN 978-07494-549-20. 


\section{Ekonomika a management}

[15] TAN, P.K. Language as Commodity. Global Structures, Local Marketplaces. London: Continuum International Publishing Group, 2008. ISBN 978-18-4706-422-6.

[16] WRIGHT, M. Gower Handbook of Internal Communication. 2nd ed. Farnham: Gower Publishing Limited, 2009. 496 p. ISBN 978-0-566-08689-2.

[17] YATES, K. Internal Communication Effectiveness Enhances Bottom-Line Results. Journal of Organizational Excellence. 2006, Vol. 25, Iss. 3, pp. 71-79. ISSN 1932-2054.

[18] MOHELSKÁ, H., KARLÍČEK, M., CHYTKOVÁ, Z., FISCHER, J., HOŘEJŠ, N. The Role of Marketing in Multinational Subsidiaries: Standardization versus Localization. $E+M$ Ekonomie a Management. 2013, Vol. 16, Iss. 1, pp. 138-148. ISSN 1212-3609.
Ing. Jana Holá, Ph.D.

University of Pardubice

Faculty of Health Studies

Department of Informatics,

Management and Radiology jana.hola@upce.cz

\section{Mgr. et Mgr. Marcel Pikhart, Ph.D.}

University of Hradec Kralove

Faculty of Information Technology and Management

Department of Applied Linguistics marcel.pikhart@uhk.cz 


\section{Abstract}

\section{THE IMPLEMENTATION OF INTERNAL COMMUNICATION SYSTEM AS A WAY TO COMPANY EFFICIENCY

\author{
Jana Holá, Marcel Pikhart
}

The paper focuses on the management of internal communication inasmuch it can influence company efficiency and competitiveness in the current global business market. The implementation of internal communication strategies can be a way to enhance company efficiency and it can also increase and support engagement of employees in everyday company operations and connect the employees expectations and increase their morale. On the other hand, inefficient communication is a stress factor paralysing the key functions in a company structure and its strategy. The conducted research has proved the crucial role of internal communication in producing superior financial results and the implementation of internal communication into strategic management is considered to be a necessary condition for efficient internal communication in any company operating in the global market. The implementation of internal communication into strategic management of the company means accepting the importance of staff as communicators and partners and thus seeing them as the most important asset for the company. The conducted research carried out in 252 companies operating in the Czech market has shown that strategic and systematic internal communication is important for the company profitability and its competitiveness. Small companies do not focus on internal communication as such and solve the communication issues intuitively and ad hoc, however, it is important to set certain strategies of internal communication into a company management so that the problems of insufficient communication are eliminated as much as possible. The research has proved that in the companies which systematically manage their internal communication the efficiency evaluation of the internal communication is significantly higher than in the ones which do not manage their internal communication systematically, and in the companies which include internal communication in their strategic management the evaluation of efficiency of internal communication is significantly higher than in other companies.

Key Words: Management, internal communication, company communication, competitiveness, profitability.

JEL Classification: M31, M12.

DOI: 10.15240/tul/001/2014-2-012 